\title{
Serum Anti-Collagen IV IgM and IgG Antibodies as Indicators of Low Vascular Turnover of Collagen IV in Patients with Long-Term Complications of Type 2 Diabetes
}

\author{
Krasimir Kostov 1,*(D) and Alexander Blazhev ${ }^{2}$ (D) \\ 1 Department of Pathophysiology, Medical University-Pleven, 1 Kliment Ohridski Str., 5800 Pleven, Bulgaria \\ 2 Department of Biology, Medical University-Pleven, 1 Kliment Ohridski Str., 5800 Pleven, Bulgaria; \\ yalishanda9@gmail.com \\ * Correspondence: dr.krasi_kostov@abv.bg; Tel.: +359-889-257-459
}

Citation: Kostov, K.; Blazhev, A. Serum Anti-Collagen IV IgM and IgG Antibodies as Indicators of Low Vascular Turnover of Collagen IV in Patients with Long-Term Complications of Type 2 Diabetes. Diagnostics 2021, 11, 900. https: / / doi.org/10.3390/diagnostics11050900

Academic Editor: Paolo Zamboni

Received: 21 April 2021

Accepted: 17 May 2021

Published: 19 May 2021

Publisher's Note: MDPI stays neutral with regard to jurisdictional claims in published maps and institutional affiliations.

Copyright: (c) 2021 by the authors. Licensee MDPI, Basel, Switzerland. This article is an open access article distributed under the terms and conditions of the Creative Commons Attribution (CC BY) license (https:/ / creativecommons.org/licenses/by/ $4.0 /)$.

\begin{abstract}
Thickening of the vascular basement membrane (BM) is a fundamental structural change in the small blood vessels in diabetes. Collagen type IV (CIV) is a major component of the BMs, and monitoring the turnover of this protein in type 2 diabetes (T2D) can provide important information about the mechanisms of vascular damage. The aim of the study was through the use of non-invasive biomarkers of CIV (autoantibodies, derivative peptides, and immune complexes) to investigate vascular turnover of CIV in patients with long-term complications of T2D. We measured serum levels of these biomarkers in 59 T2D patients with micro- and/or macrovascular complications and 20 healthy controls using an ELISA. Matrix metalloproteinases-2 and -9 (MMP-2 and MMP-9) were also tested. In the T2D group, significantly lower levels of CIV markers and significantly higher levels of MMP-2 and MMP-9 were found compared to controls. A significant positive correlation was found between IgM antibody levels against CIV and MMP-2. These findings suggest that vascular metabolism of CIV is decreased in T2D with long-term complications and show that a positive linear relationship exists between MMP-2 levels and CIV turnover in the vascular wall.
\end{abstract}

Keywords: type 2 diabetes; collagen IV; vascular basement membrane; matrix metalloproteinases-2 and -9 ; diabetic vascular complications

\section{Introduction}

Diabetes mellitus is a chronic disease with an increasing frequency in recent decade. The International Diabetes Federation (IDF) estimates that the global number of people with diabetes will increase to 693 million by 2045 [1]. Type 2 diabetes (T2D) accounts more than $90 \%$ of all diagnosed diabetes cases and is among the leading causes of cardiovascular morbidity and mortality [2]. In patients with T2D, the treatment of cardiovascular disease can be improved by identifying specific biomarkers to assess vascular changes [3].

Collagen (COL) is one of the primary load bearing components in the arterial wall and plays an important role in vascular function in both normal and pathological processes [4,5]. In patients with T2D, monitoring the turnover of this structural protein may provide important information about the mechanisms of vascular damage [6-12]. As a result of degradation processes occurring in the vascular extracellular matrix (ECM), the released COL peptides enter the circulation and can be detected and examined in the serum [13]. In this regard, the measurement of non-invasive markers of COL degradation, such as specific autoantibodies (autoAbs), COL-derived peptides (DP), and circulating immune complexes (CIC) of the COL, may be useful for monitoring the development of vascular complications in T2D [14-16].

Basement membranes (BMs) are a main focus of scientific research due to their role in the pathogenesis of a number of diseases [17]. Diabetes is a "BM disease", in which microvascular damage of the capillaries is characterized by thickening of the BMs [18-20]. COL type IV (CIV) is a major vascular BM protein and represents up to $50 \%$ of all $\mathrm{BM}$ 
proteins [21,22]. Unlike fibrillar COLs (I, II, and III), CIV forms a network structure and is considered to be crucial for vascular BM assembly and stability [23]. There are six $\alpha$ chains $(\alpha 1-\alpha 6)$ that can be used to make the trimers of CIV. Predominant isoform, however, consists of two $\alpha 1$ and one $\alpha 2$ chain [ $\alpha 1$ (IV) $]_{2} \alpha 2$ (IV) [24-26]. Inside cells, the three $\alpha$-chains assemble forming triple helical molecules, termed protomers, which oligomerize outside the cells into a supramolecular network [27].

An important factor for the development of vascular complications in T2D is the imbalanced turnover of CIV in the vessel wall $[8,10-12,14]$. As a result of the underlying disease, CIV can acquire immunogenic properties and the ability to induce a humoral immune response $[13,28,29]$. Processing of CIV by matrix metalloproteinases (MMPs) gives rise to the release of fragments that are able to behave as epitopes, since they can be bound by circulating Abs, forming CIC of CIV (CIC-CIV) [30,31]. Proteolysis of CIV is accompanied by the release of DP (CIV-DP) into the bloodstream, which is followed by the production of specific anti-CIVAbs (ACIVAbs) from IgM, IgG, and IgA classes (ACIVAbs IgM, ACIVAbs IgG, and ACIVAbs IgA) [14,32,33]. These autoAbs can serve as valuable control biomarkers for the turnover of CIV in the vascular ECM. The coexistence of T2D and hypertension (HTN) further disrupts the metabolism of CIV, leading to greater stiffness of the small arteries and enhanced structural alterations in the systemic microcirculation [12].

To examine CIV turnover in the vascular ECM, we tested the serum levels of ACIVAbs IgM, ACIVAbs IgG, CIV-DP, CIC-CIV, free ACIVAbs, MMP-2, and MMP-9 in patients with T2D by ELISA, comparing the results with those of matched healthy control group.

\section{Materials and Methods}

\subsection{Characteristics of the Study Population}

The study population consisted of 79 people: Control group $(n=20$; mean age $61.5 \pm 11.4$ years), individuals without diabetes mellitus, HTN, or vascular diseases; T2D group ( $n=59$; mean age $60.8 \pm 14.7$ years; mean disease duration of $10.1 \pm 7.8$ years), patients with long-term micro- and/or macrovascular complications. The number of patients was higher than that of controls to ensure greater statistical representation of the population with T2D vascular complications. The incidence of microangiopathy in the T2D group $(n=50)$ was $85 \%$, and the incidence of macroangiopathy $(n=18)$ was $31 \%$. Nine patients had both microvascular and macrovascular disease. The clinical characteristics of the groups are shown in Table 1.

\subsection{Screening of the Patients and Controls}

The patients and control participants were screened for microangiopathy using ophthalmoscopy and/or assessment of $24 \mathrm{~h}$ urine albumin excretion. Macroangiopathy in the T2D group was evaluated on the basis of clinical evidence for coronary artery disease, cerebrovascular disease, peripheral arterial disease, and/or history for acute arterial vascular events. Control persons were screened for macroangiopathy by physical examination, blood pressure (BP) measurement, electrocardiogram (ECG) testing, measuring cholesterol levels, data on obesity and smoking, and family history.

\subsection{Immunological and Biochemical Assays}

To measure the levels of ACIVAbs, CIV-DP, CIC-CIV, free ACIVAbs, MMP-2, MMP-9, and the other laboratory parameters, blood was drawn into tubes containing a clot activator and was centrifuged at $2500 \mathrm{rpm}$ for $10 \mathrm{~min}$ to separate the serum. Until the immunological assay, the serums were stored at $-70^{\circ} \mathrm{C}$.

\subsubsection{Determination of ACIVAbs IgM and ACIVAbs IgG}

To measure the ACIVAbs IgM and ACIVAbs IgG concentrations, a sandwich ELISA was used. The assays were performed as follows: microtiter 96-well polystyrene plates were coated with $100 \mu \mathrm{L}$ of $10 \mu \mathrm{g} / \mathrm{mL}$ of human CIV (Sigma-Aldrich, St. Louis, MO, USA), followed by an overnight incubation at $4{ }^{\circ} \mathrm{C}$. Then, $100 \mu \mathrm{L}$ serum sample (diluted 
1:10) was placed in each well of the microtiter plates and incubated for $1 \mathrm{~h}$ at $37^{\circ} \mathrm{C}$. After washing, $100 \mu \mathrm{L}$ of goat anti-human IgM Ab, Fc5 $\mu$, HRP conjugate (AP114P, Sigma-Aldrich, St. Louis, MO, USA), or goat anti-human IgG Ab, Fc, and HRP conjugate (AP113P, SigmaAldrich, St. Louis, MO, USA), respectively, were added to each well for $1 \mathrm{~h}$ at $37{ }^{\circ} \mathrm{C}$. All immunoconjugates were diluted 1:10,000. Then, $100 \mu \mathrm{L}$ of ortho-phenylenediamine ( $4 \mathrm{mg} / \mathrm{mL}$ in $0.05 \mathrm{M}$ citrate buffer) was added as a colorimetric substrate for $30 \mathrm{~min}$. The reaction was stopped by adding $50 \mu \mathrm{L}$ of $4 \mathrm{M} \mathrm{H}_{2} \mathrm{SO}_{4}$ to each well, and the optical density was measured with a micro-ELISA plate reader (Coulter Microplate Reader UV Max, Molecular Devices Corp., Menlo Park, CA, USA) at a wavelength of $492 \mathrm{~nm}$.

Table 1. Clinical characteristics of the groups in the study population.

\begin{tabular}{|c|c|c|}
\hline \multirow{2}{*}{ Variables } & Healthy Control Subjects & Patients with T2D \\
\hline & $(n=20)$ & $(n=59)$ \\
\hline Men, $n(\%)$ & $10(50.0)$ & $25(42.0)$ \\
\hline Women, $n(\%)$ & $10(50.0)$ & $34(58.0)$ \\
\hline Age, years 1 & $61.5 \pm 11.4$ & $60.8 \pm 14.7$ \\
\hline Duration of $\mathrm{T} 2 \mathrm{D}^{1}$ & $\mathrm{~N} / \mathrm{A}^{2}$ & $10.1 \pm 7.8$ \\
\hline $\mathrm{SBP}, \mathrm{mmHg}^{1}$ & $121.5 \pm 8.6$ & $149.2 \pm 16.7^{* * *}$ \\
\hline $\mathrm{DBP}, \mathrm{mmHg}^{1}$ & $78.2 \pm 7.5$ & $83.0 \pm 10.4$ \\
\hline $\mathrm{BMI}, \mathrm{kg} / \mathrm{m}^{21}$ & $24.9 \pm 2.4$ & $28.4 \pm 4.5^{* * *}$ \\
\hline Smokers, $n(\%)$ & $4(20)$ & $9(15)$ \\
\hline $\operatorname{HbA} 1 \mathrm{c}(\%)^{1}$ & $\mathrm{~N} / \mathrm{A}^{2}$ & $7.5 \pm 1.8$ \\
\hline $\mathrm{TC}, \mathrm{mmol} / \mathrm{L}^{1}$ & $4.2 \pm 0.7$ & $5.2 \pm 1.8^{*}$ \\
\hline LDL-C, $\mathrm{mmol} / \mathrm{L}^{1}$ & $2.8 \pm 0.8$ & $3.0 \pm 1.1$ \\
\hline $\mathrm{HDL}-\mathrm{C}, \mathrm{mmol} / \mathrm{L}^{1}$ & $1.2 \pm 0.2$ & $1.0 \pm 0.3^{* * *}$ \\
\hline $\mathrm{TG}, \mathrm{mmol} / \mathrm{L}^{1}$ & $1.4 \pm 0.4$ & $2.7 \pm 3.0$ \\
\hline $\mathrm{CRP}, \mathrm{mg} / \mathrm{L}^{1}$ & $1.1 \pm 0.9$ & $8.4 \pm 7.9^{* * *}$ \\
\hline $\mathrm{MMP}-2, \mathrm{ng} / \mathrm{mL}^{1}$ & $30.68 \pm 8.4$ & $36.22 \pm 11.5$ * \\
\hline MMP-9, ng/mL 1 & $25.84 \pm 12.7$ & $38.48 \pm 20.7^{* *}$ \\
\hline Neuropathy, $n(\%)$ & $\mathrm{N} / \mathrm{A}^{2}$ & $8(14.0)$ \\
\hline Microangiopathy, $n(\%)$ & $\mathrm{N} / \mathrm{A}^{2}$ & $50(85.0)$ \\
\hline Macroangiopathy, $n(\%)$ & $\mathrm{N} / \mathrm{A}^{2}$ & $18(31.0)$ \\
\hline
\end{tabular}

${ }^{*} p<0.05,{ }^{* *} p<0.01 ;{ }^{* * *} p<0.001 ;{ }^{1}$ Mean $\pm \mathrm{SD} ;{ }^{2} \mathrm{~N} / \mathrm{A}$, not available; SBP: systolic blood pressure; DBP: diastolic blood pressure; BMI: body mass index; TC: total cholesterol; LDL-C: low-density lipoprotein cholesterol; HDL-C: high-density lipoprotein cholesterol; TG: triglyceride; CRP: C-reactive protein; MMP-2: matrix metalloproteinase2; MMP-9: matrix metalloproteinase-9.

\subsubsection{Determination of CIV-DP}

To measure CIV-DP concentrations, a sandwich ELISA was used. The assay was performed as follows: each well of the microtiter plate was sensitized with $100 \mu \mathrm{L}$ of $10 \mu \mathrm{g} / \mathrm{mL}$ of mouse monoclonal antibody to collagen IV [COL-94] (Cat. No. ab6311, Abcam, Cambridge, UK), followed by an overnight incubation at $4{ }^{\circ} \mathrm{C}$. Then, $100 \mu \mathrm{L}$ serum sample (diluted 1:5) was placed in each well of a microtiter plate and incubated for $1 \mathrm{~h}$ at $37^{\circ} \mathrm{C}$. After washing, $100 \mu \mathrm{L}$ of rabbit anti-human CIV polyclonal antibody (Cat. No. ab6586, Abcam, Cambridge, UK) (diluted 1:2000) was allowed to react in each well at $37^{\circ} \mathrm{C}$ for $1 \mathrm{~h}$. After washing, peroxidase-conjugated goat anti-rabbit IgG H\&L (HRP) (Cat. No. ab205718, Abcam, Cambridge, UK) diluted 10,000 fold was added to each well. The plate was incubated for $1 \mathrm{~h}$ at $37^{\circ} \mathrm{C}$. Then, $100 \mu \mathrm{L}$ of ortho-phenylenediamine $(4 \mathrm{mg} / \mathrm{mL}$ in $0.05 \mathrm{M}$ citrate buffer) was added as a colorimetric substrate for $30 \mathrm{~min}$. The reaction was stopped by adding $50 \mu \mathrm{L}$ of $4 \mathrm{M} \mathrm{H}_{2} \mathrm{SO}_{4}$ to each well, and the optical density was measured with a micro-ELISA plate reader (Coulter Microplate Reader UV Max, Molecular Devices Corp., Menlo Park, CA, USA) at a wavelength of $492 \mathrm{~nm}$.

\subsubsection{Determination of CIC-CIV}

For the determination of CIC-CIV, a method based on C3-binding glycoprotein was used: Complement-Inhibiting Factor (CIF)-Enzyme Linked Immunosorbent Assay (CIF- 
ELISA) [16]. The assay was performed as follows: microtiter 96-well polystyrene CIF-ELISA plates were prepared by incubation of the wells with CIF $(20 \mu \mathrm{g} / \mathrm{mL}$ in $0.2 \mathrm{M}$ carbonatebicarbonate buffer, $\mathrm{pH} 9.6$ ) overnight at $4{ }^{\circ} \mathrm{C}$. After repeatedly washed in order to remove unbound CIF, human sera $(100 \mu \mathrm{L})$ were added to the plates and incubated for $1 \mathrm{~h}$ at $37^{\circ} \mathrm{C}$. After washing, $100 \mu \mathrm{L}$ of rabbit anti-human CIV polyclonal antibody (Cat. No. ab6586, Abcam, Cambridge, UK) (diluted 1:2000) was allowed to react in each well at $37^{\circ} \mathrm{C}$ for $1 \mathrm{~h}$. After washing, peroxidase-conjugated goat anti-rabbit IgG H\&L (HRP) (Cat. No. ab205718, Abcam, Cambridge, UK) diluted 10,000 fold was added to each well. The plate was incubated for $1 \mathrm{~h}$ at $37^{\circ} \mathrm{C}$. Then, $100 \mu \mathrm{L}$ of ortho-phenylenediamine $(4 \mathrm{mg} / \mathrm{mL}$ in $0.05 \mathrm{M}$ citrate buffer) was added as a colorimetric substrate for $30 \mathrm{~min}$. The reaction was stopped by adding $50 \mu \mathrm{L}$ of $4 \mathrm{M} \mathrm{H}_{2} \mathrm{SO}_{4}$ to each well, and the optical density was measured with a micro-ELISA plate reader (Coulter Microplate Reader UV Max, Molecular Devices Corp., Menlo Park, CA, USA) at a wavelength of $492 \mathrm{~nm}$.

\subsubsection{Determination of Free ACIVAbs}

Circulating free ACIVAbs were determined using a two-step method [34]: (1) CIFELISA for elimination of the immune complexes of collagen IV, followed by (2) Collagen IV-specific ELISA for determination of free anti-collagen IV Ab. The assay was performed as follows: microtiter 96-well polystyrene CIF-ELISA plates were prepared by incubation of the wells with CIF $(20 \mu \mathrm{g} / \mathrm{mL}$ in $0.2 \mathrm{M}$ carbonate-bicarbonate buffer, $\mathrm{pH}$ 9.6) overnight at $4{ }^{\circ} \mathrm{C}$. After repeatedly washed in order to remove unbound $\mathrm{CIF}$, human sera $(100 \mu \mathrm{L})$ were added to the plates and incubated for $1 \mathrm{~h}$ at $37^{\circ} \mathrm{C}$. At the end of the incubation period, the samples were transferred from the CIF plates to the 96-well polystyrene plate coated with $100 \mu \mathrm{L}$ of $10 \mu \mathrm{g} / \mathrm{mL}$ of human CIV (\#CC076 Sigma-Aldrich, St. Louis, MO, USA) at room temperature for $3 \mathrm{~h}$. After washing, $100 \mu \mathrm{L}$ of rabbit monoclonal [H169-1-5] anti-human IgG Fc (Cat. No. ab125909, Abcam, Cambridge, UK) (diluted 1:2000) were added to each well for $1 \mathrm{~h}$ at $37^{\circ} \mathrm{C}$. The wells were washed and peroxidase-conjugated goat anti-rabbit IgG H\&L (HRP) (Cat. No. ab205718, Abcam, Cambridge, UK) diluted 10,000 fold was then added to each well. Then, $100 \mu \mathrm{L}$ of ortho-phenylenediamine $(4 \mathrm{mg} / \mathrm{mL}$ in $0.05 \mathrm{M}$ citrate buffer) was added as a colorimetric substrate for $30 \mathrm{~min}$. The reaction was stopped by adding $50 \mu \mathrm{L}$ of $4 \mathrm{M} \mathrm{H}_{2} \mathrm{SO}_{4}$ to each well, and the optical density was measured with a micro-ELISA plate reader (Coulter Microplate Reader UV Max, Molecular Devices Corp., Menlo Park, CA, USA) at a wavelength of $492 \mathrm{~nm}$.

\subsubsection{Determination of MMP-2 and MMP-9}

To measure MMP-2 and MMP-9 concentrations, ELISA kits from R\&D Systems (Cat. No. DMP2F0 and Cat. No. DMP900) (Minneapolis, MN, USA) were used according to the manufacturer's instructions. Serum samples were assayed at $450 \mathrm{~nm}$ on an automatic micro-ELISA plate reader (Coulter Microplate Reader UV Max, Molecular Devices Corp., Menlo Park, CA, USA).

\subsubsection{Biochemical Analysis}

The assays were performed using automatic biochemistry analyzer. $\mathrm{HbA1c}$ and CRP were measured by a turbidimetric immunoassay. Enzymatic methods were used to measure of total cholesterol (TC), low-density lipoprotein cholesterol (LDL-C), high-density lipoprotein cholesterol (HDL-C), and triglyceride (TG).

\subsection{Clinical Tests and Procedures}

All patients were subjected to routine nephrologic (renal ultrasound, creatinine, blood urea nitrogen, urinary albumin excretion), ophthalmic (visual acuity test, ophthalmoscopy, tonometry), and neurologic (muscle reflexes, electromyography) examination. BP was measured using a standard cuff mercury sphygmomanometer on the left arm in a sitting position, after a 5-10 min rest. Normal BP was defined as SBP 120-129 $\mathrm{mmHg}$ and DBP 80-84 mmHg. HTN was defined as SBP $\geq 140 \mathrm{mmHg}$ and/or DBP $\geq 90 \mathrm{mmHg}$. A 
twelve-lead ECG was performed using standard equipment. Body mass index (BMI) was calculated, using the standard metric BMI formula $\left(\mathrm{Kg} / \mathrm{m}^{2}\right)$. BMI between 18.5-24.9 was considered normal, 25-29.9 was considered overweight, and $\geq 30$ was considered obese.

\subsection{Statistical Analysis}

Statistical analyses were performed using SPSS 23.0 software (SPSS, Inc., Chicago, IL, USA). The data were expressed as mean \pm standard deviation (SD). The differences between the groups were assessed by Student's unpaired $t$-test. Correlation analysis was performed with Pearson's correlation test. Values of $p<0.05$ were considered statistically significant.

\section{Results}

3.1. Comparison of the Levels of ACIVAbs IgM and ACIVAbs IgG between the T2D and Control Groups

To measure serum levels of ACIVAbs IgM and ACIVAbs IgG by ELISA, goat antihuman IgM Ab, Fc5 $\mu$, horseradish peroxidase (HRP) conjugate or goat anti-human IgG $\mathrm{Ab}, \mathrm{Fc}$, and HRP conjugate, respectively, were used. The levels of ACIVAbs IgM were significantly lower in the T2D group compared to healthy controls $(0.12 \pm 0.06$ vs. $0.18 \pm 0.09$; $p=0.016$; Figure 1A). The levels of ACIVAbs IgG were also lower in the T2D group than in controls, but the difference was not statistically significant $(0.28 \pm 0.14$ vs. $0.30 \pm 0.11$; $p=0.54$; Figure 1B). We also found a positive correlation between ACIVAbs IgM and MMP-2 in the T2D group ( $r=0.343 ; p=0.008$; Figure $1 C)$.
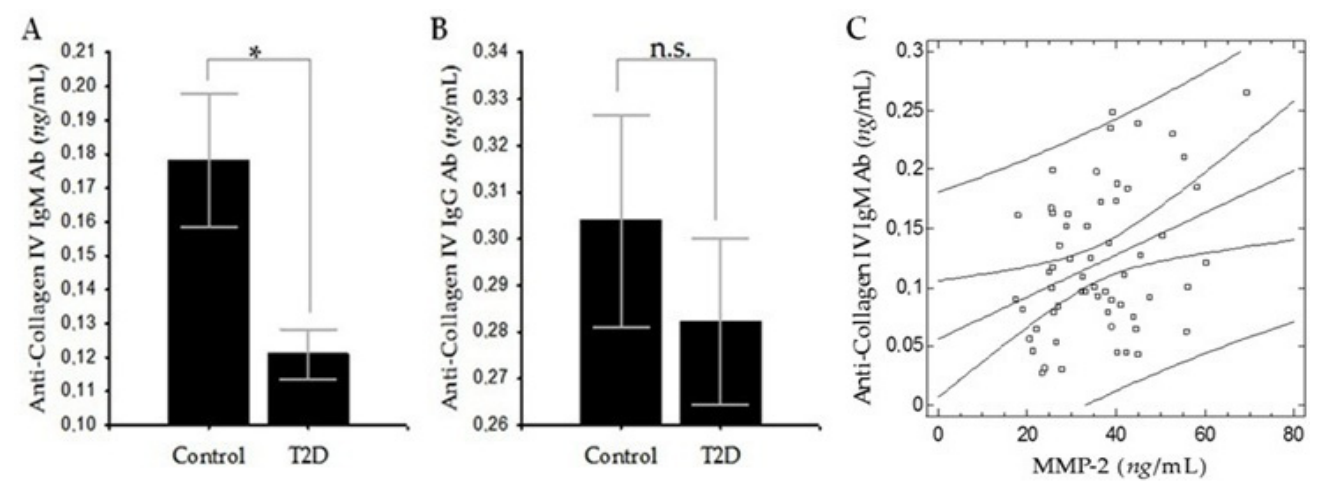

Figure 1. (A) Serum levels of ACIVAbs IgM in T2D group vs. control group. (B) Serum levels of ACIVAbs IgG in T2D group vs. control group. (C) Relationship between ACIVAbs IgM and MMP-2 in the T2D group. Data are represented as mean \pm SD. ${ }^{*} p<0.05$, n.s. - not significant.

\subsection{Comparison of the Levels of CIV-DP, CIC-CIV, and Free ACIVAbs IgG between the T2D and Control Groups}

To measure serum levels of CIV-DP by ELISA, rabbit anti-human CIV polyclonal $\mathrm{Ab}$ and peroxidase-conjugated goat anti-rabbit IgG were used. We found that CIV-DP levels were significantly lower in T2D group compared to healthy controls $(0.74 \pm 0.27$ vs. $1.16 \pm 0.25 ; p<0.001$; Figure $2 \mathrm{~A}$ ). To measure CIC-CIV levels, a method based on C3-binding glycoprotein was used: Complement-Inhibiting Factor (CIF)-Enzyme Linked Immunosorbent Assay (CIF-ELISA) [16]. CIF catches out different CIC in the serum, and to differentiate only CIC-CIV, we used rabbit anti-human CIV polyclonal IgG Abs. We found that CIC-CIV levels were also significantly reduced in T2D group than in controls $(0.47 \pm 0.13$ vs. $0.68 \pm 0.15 ; p<0.001$; Figure $2 B)$. Circulating free ACIVAbs IgG were determined using a two-step method [34]: 1) CIF-ELISA for elimination of CIC-CIV, followed by 2) CIV-specific ELISA for determination of free ACIVAbs IgG, using rabbit monoclonal anti-human IgG, Fc. The results show that the levels of free ACIVAbs IgG in the T2D group were significantly higher compared to those of the control group $(0.58 \pm 0.13$ vs. $0.42 \pm 0.07 ; p<0.001$; Figure 2C). It should be noted that ACIVAbs IgM and ACIVAbs IgG as biomarkers reflect common levels of these classes of ACIVAbs measured in controls 
and patients with T2D. The difference between ACIVAbs IgG and free ACIVAbs IgG as biomarkers is that the latter does not reflect the total levels of ACIVAbs IgG, but only that part of ACIVAbs IgG that does not participate in the formation of CIC-CIV.

A

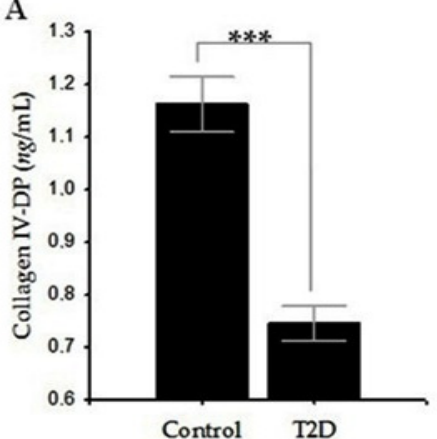

B

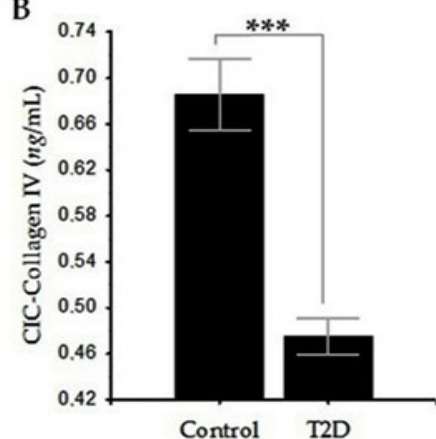

C

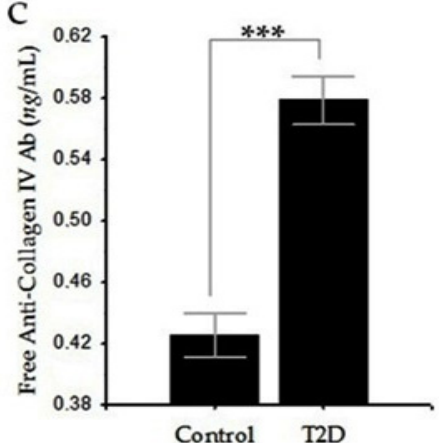

Figure 2. (A) Serum levels of CIV-DP in T2D group vs. control group. (B) Serum levels of CIC-CIV in T2D group vs. control group. (C) Serum levels of free ACIVAbs IgG in T2D group vs. control group. Data are represented as mean $\pm \mathrm{SD}$. ${ }^{* *} p<0.001$.

\section{Discussion}

Vascular BM thickening is a fundamental structural alteration of small blood vessels in diabetes. Research has established hyperglycemia as the primary causal factor mediating this alteration [35]. BM thickening is most evident in the eye (diabetic retinopathy, DR) [18,35] and the kidney (diabetic nephropathy, DN) [20,36]. Changes in the BMs of retinal vessels in DR may develop along with or without DN [36]. It is assumed that excess synthesis and/or decreased degradation of BM components are a major contributing factors to its thickening [35,37-39]. Metabolic dysregulation of COL and, in particular, of CIV play an important role in this process $[7,8,11,12,39]$.

We found in patients with T2D significantly lower levels of ACIVAbs IgM (Figure 1A) and CIV-DP (Figure 2A) compared to controls, which suggests an imbalance in the processes of synthesis and degradation of CIV in the vascular wall. We also found lower levels of ACIVAbs IgG compared to controls without being significant (Figure 1B). Identical to our results with lower but non-significant levels of ACIVAbs IgM and ACIVAbs IgA in patients with T2D than in controls have been also reported [33]. These data indicate that vascular metabolism of CIV is decreased in T2D with long-term complications, which probably leads to its excessive deposition in the BMs of the microcirculation. A similar hypothesis is further supported by the data on reduced serum CIC-CIV levels that we found in patients with T2D (Figure 2B). To support these conclusions, we examined this portion of ACIVAbs IgG that remain unbound with CIV-DP in the blood circulation and do not participate in the formation of CIC-CIV (free ACIVAbs IgG). The results showed that the levels of free ACIVAbs IgG were significantly higher compared to those of the healthy controls (Figure 2C). A possible explanation for these data is that as a result of reduced CIV degradation, most of the circulating ACIVAbs IgG remain unbound to metabolites of CIV, leading to their increased serum levels. Experimental data from tissue samples also support our results. It was found that BMs of retinal vessels in diabetic rats contain increased amounts of the $\alpha 1$ (IV) chain of collagen, as well as of the $\beta 1$ and $\gamma$ chains of laminin and fibronectin, indicating increased accumulation of matrix components [36,40]. It has also been reported that collagens III and IV in the kidneys of streptozotocin (STZ)diabetic rats accumulate to a greater extent than in those of control rats $[36,41]$. In humans, it has been demonstrated that CIV along with collagens type I, III, and V was upregulated in the retinas of patients with DR compared to that in retinas of non-diabetic subjects $[7,8]$. In DN, podocytes adopt a "promatrix phenotype", followed by preferential deposition of CIV in glomerular basement membrane (GBM) [20,30,42].

In diabetes, vascular BM thickening occurs not only due to excessive synthesis and deposition of ECM components, but also due to their decreased degradation [20,38]. 
Hyperglycemia-induced dysregulated of MMPs may be an important factor for increased CIV deposition in the vascular BMs [30]. The subgroup of MMPs known as gelatinases, in particular gelatinase A (MMP-2) and gelatinase B (MMP-9), can degrade COL and denatured COL (gelatin), and their altered activity might be implicated in the pathophysiology of diabetes complications [15]. In our study, we found significantly higher serum levels of MMP-2 and MMP-9 in the T2D patients compared to controls (Table 1) and a positive correlation between MMP-2 and ACIVAbs IgM in the T2D group, showing the linear relationship between MMP-2 levels and vascular CIV turnover (Figure 1C). A possible explanation for these results is that both gelatinases could be involved in the development of vascular complications in T2D, but with a predominant role of MMP-2 in CIV metabolism. Considering this correlation at the biological level, it can be concluded that the local regulation of MMP-2 activity may play an important role in the pathogenesis of diabetic vascular complications by affecting CIV metabolism in the vascular wall. In this regard, some authors suggest that MMP-2 may be a good index of the severity of microangiopathy, and MMP-9 may be a marker of macroangiopathy in diabetes [43]. In diabetes with long-term complications, increased expression of tissue inhibitors of MMPs (TIMPs) has been observed, which may suppress enhanced MMP activity [44]. Elevated circulating levels of MMP-2 and MMP-9 along with elevated levels of TIMP-1 [45-47] were observed in patients with DR compared to diabetic patients without retinopathy. Data suggesting a link between MMP-2 dysregulation and DN also exist. Rodent models of diabetes reveal decreased expression and/or proteolytic activity of MMP-2 in renal tissues [48], suggesting decreased degradation of CIV in the GBM. In patients with DN, increased expression and activity of TIMP-1, TIMP-2, and TIMP-3 can contribute to excessive deposition of ECM components in GBM [20]. Decreased activity of MMP-2 and MMP-9 is observed with increased activity of TIMP-1, which leads to excessive deposition of CIV and fibronectin in the GBM [49]. TIMP-2, which is a specific inhibitor of MMP-2, was strongly increased in glomerular epithelial cells cultured in high glucose and also in the kidneys of STZ-diabetic rats [36]. TIMP-3, the most highly expressed TIMP in the kidney, was upregulated in both experimental and human DN. In diabetic mouse models, TIMP-3 knockout results in GBM thickening and albuminuria [20]. Systemic concentrations of MMP-2 and MMP-9 were also increased in peripheral arterial disease and HTN, which are present in a significant proportion of patients with T2D [50,51]. In addition, glucose-induced modifications of the vascular ECM not only result in increased deposition of structural proteins, but also renders glycated components, such as CIV, less susceptible to proteolysis by MMPs [36].

The strength of our study is that it describes a specific immunological method for examining vascular CIV turnover in patients with T2D. A limitation of the study is the relatively small number of studied persons, which requires these results to be confirmed in larger studies.

\section{Conclusions}

Given the severe consequences of vascular damage in patients with T2D, new noninvasive methods are needed to assess vascular changes. The study of vascular metabolism of CIV by measuring the levels of specific immunological biomarkers such as ACIVAbs, CIV-DP, CIC-CIV, and free ACIVAbs can be used to monitor the development of vascular complications and the therapeutic response in patients with T2D. Our research of these biomarkers showed significantly lower serum levels of ACIVAbs IgM, CIV-DP, CIC-CIV, and significantly higher levels of free ACIVAbs IgG in the T2D group compared to controls. These results suggest that vascular metabolism of CIV is decreased in patients with longterm complications of T2D, which may lead to its excessive accumulation in capillary BMs and their thickening. The data also suggest that MMP-2 may be involved in the development of vascular complications in T2D, which is confirmed by the existence of a positive linear relationship between the levels of MMP-2 and ACIVAbs IgM. Considering this correlation at the biological level, it can be concluded that up- or downregulation 
of MMP-2 activity may play an important role in the pathogenesis of diabetic vascular complications by affecting CIV metabolism in the vascular wall.

Author Contributions: Conceptualization, software, formal analysis, writing-original draft preparation, review and editing, visualization, K.K.; methodology, resources, A.B. All authors have read and agreed to the published version of the manuscript.

Funding: The APC was funded by Medical University-Pleven, Bulgaria.

Institutional Review Board Statement: The study was conducted according to the guidelines of the Declaration of Helsinki, and approved by the Research Ethics Committee of Medical UniversityPleven (IRB approval No. 314-REC/17.06.2014; Prot. 29).

Informed Consent Statement: Informed consent was obtained from all subjects involved in the study.

Data Availability Statement: The authors confirm that the data supporting the findings of this report are available within the article.

Conflicts of Interest: The authors declare no conflict of interest.

\section{References}

1. Cho, N.; Shaw, J.E.; Karuranga, S.; Huang, Y.; da Rocha Fernandes, J.D.; Ohlrogge, A.W.; Malanda, B. IDF diabetes atlas: Global estimates of diabetes prevalence for 2017 and projections for 2045. Diabetes Res. Clin. Pract. 2018, 138, $271-281$. [CrossRef] [PubMed]

2. Dougherty, T.; Heile, M. Type 2 diabetes in the US managed care setting: The burden of disease and rationale for an oral glucagon-like peptide-1 receptor agonist. Am. J. Manag. Care 2020, 26, S325-S334. [PubMed]

3. Bachmann, K.N.; Wang, T.J. Biomarkers of cardiovascular disease: Contributions to risk prediction in individuals with diabetes. Diabetologia 2018, 61, 987-995. [CrossRef] [PubMed]

4. Holzapfel, G.A. Collagen in arterial walls: Biomechanical aspects. In Collagen; Springer: New York, NY, USA, 2008; pp. 285-324.

5. Wang, Y.; Zeinali-Davarani, S.; Zhang, Y. Arterial mechanics considering the structural and mechanical contributions of ECM constituents. J. Biomech. 2016, 49, 2358-2365. [CrossRef] [PubMed]

6. Makino, H.; Shikata, K.; Wieslander, J.; Wada, J.; Kashihara, N.; Yoshioka, K.; Ota, Z. Localization of fibril/microfibril and basement membrane collagens in diabetic glomerulosclerosis in type 2 diabetes. Diabet. Med. 1994, 11, 304-311. [CrossRef]

7. Ljubimov, A.V.; Burgeson, R.E.; Butkowski, R.J.; Couchman, J.R.; Zardi, L.; Ninomiya, Y.; Sado, Y.; Huang, Z.S.; Nesburn, A.B.; Kenney, M.C. Basement membrane abnormalities in human eyes with diabetic retinopathy. J. Histochem. Cytochem. 1996, 44, 1469-1479. [CrossRef]

8. Roy, S.; Maiello, M.; Lorenzi, M. Increased expression of basement membrane collagen in human diabetic retinopathy. J. Clin. Investig. 1994, 93, 438-442. [CrossRef]

9. Inukai, T.; Fujiwara, Y.; Tayama, K.; Aso, Y.; Takemura, Y. Serum levels of carboxy-terminal propeptide of human type I procollagen are an indicator for the progression of diabetic nephropathy in patients with Type 2 diabetes mellitus. Diabetes Res. Clin. Pract. 2000, 48, 23-28. [CrossRef]

10. Kotajima, N.; Kimura, T.; Kanda, T.; Obata, K.; Kuwabara, A.; Fukumura, Y.; Kobayashi, I. Type IV collagen as an early marker for diabetic nephropathy in non-insulin-dependent diabetes mellitus. J. Diabetes Complicat. 2000, 14, 13-17. [CrossRef]

11. Xu, X.; Wu, Z.; Zhou, Q.; Zhang, Y.; Wu, D. The role of determining the levels of serum collagen type IV in diagnosing early diabetic nephropathy. Ren. Fail. 2002, 24, 747-753. [CrossRef]

12. Yano, Y.; Ura, H.; Sumida, Y.; Gabazza, E.C.; Misaki, M.; Shima, T. Serum 7S domain of type IV collagen levels in essential hypertension and hypertensive type 2 diabetic patients. Diabet. Med. 1997, 14, 466-471. [CrossRef]

13. Nicoloff, G.; Baydanoff, S.; Petrova, C.; Christova, P. Serum antibodies to collagen type IV and development of diabetic vascular complications in children with type 1 (insulin-dependent) diabetes mellitus: A longitudinal study. Vascul. Pharmacol. 2002, 38, 143-147. [CrossRef]

14. Nikolov, A.G.; Nicoloff, G.; Tsinlikov, I.; Tsinlikova, I. Anti-collagen type IV antibodies and the development of microvascular complications in diabetic patients with arterial hypertension. J. IMAB 2012, 18, 315-322. [CrossRef]

15. Kostov, K.; Blazhev, A. Use of glycated hemoglobin (A1c) as a biomarker for vascular risk in type 2 diabetes: Its relationship with matrix metalloproteinases-2,-9 and the metabolism of collagen IV and elastin. Medicina 2020, 56, 231. [CrossRef] [PubMed]

16. Nicoloff, G.; Blazhev, A.; Petrova, C.; Christova, P. Circulating immune complexes among diabetic children. Clin. Dev. Immunol. 2004, 11, 61-66. [CrossRef] [PubMed]

17. Sekiguchi, R.; Yamada, K.M. Basement membranes in development and disease. Curr. Top. Dev. Biol. 2018, 130, 143-191. [PubMed]

18. Roy, S.; Kim, D. Retinal capillary basement membrane thickening: Role in the pathogenesis of diabetic retinopathy. Prog. Retin. Eye Res. 2020, 9, 100903. [CrossRef] 
19. Halfter, W.; Moes, S.; Asgeirsson, D.O.; Halfter, K.; Oertle, P.; Herraiz, E.M.; Plodinec, M.; Jenoe, P.; Henrich, P.B. Diabetes-related changes in the protein composition and the biomechanical properties of human retinal vascular basement membranes. PLOS ONE 2018, 13, e0195772. [CrossRef]

20. Marshall, C.B. Rethinking glomerular basement membrane thickening in diabetic nephropathy: Adaptive or pathogenic? Am. J. Physiol. Ren. Physiol. 2016, 311, F831-F843. [CrossRef]

21. Steffensen, L.B.; Rasmussen, L.M. A role for collagen type IV in cardiovascular disease? Am. J. Physiol. Heart Circ. Physiol. 2018, 315, H610-H625. [CrossRef]

22. Kalluri, R. Basement membranes: Structure, assembly and role in tumour angiogenesis. Nat. Rev. Cancer 2003, 3, 422-433. [CrossRef] [PubMed]

23. Hayden, M.R.; Sowers, J.R.; Tyagi, S.C. The central role of vascular extracellular matrix and basement membrane remodeling in metabolic syndrome and type 2 diabetes: The matrix preloaded. Cardiovasc. Diabetol. 2005, 4, 1-20. [CrossRef]

24. Hudson, B.G.; Reeders, S.T.; Tryggvason, K. Type IV collagen: Structure, gene organization, and role in human diseases: Molecular basis of Goodpasture and Alport syndromes and diffuse leiomyomatosis. J. Biol. Chem. 1993, 268, 26033-26036. [CrossRef]

25. Khoshnoodi, J.; Pedchenko, V.; Hudson, B.G. Mammalian collagen IV. Microsc. Res. Tech. 2008, 71, 357-370. [CrossRef] [PubMed]

26. Mk, G.; Ra, H. Collagens. Cell Tissue Res. 2010, 339, 247-257.

27. Thomsen, M.S.; Routhe, L.J.; Moos, T. The vascular basement membrane in the healthy and pathological brain. J. Cereb. Blood Flow Metab. 2017, 37, 3300-3317. [CrossRef] [PubMed]

28. Borza, D.B.; Chedid, M.F.; Colon, S.; Lager, D.J.; Leung, N.; Fervenza, F.C. Recurrent Goodpasture's disease secondary to a monoclonal IgA1-K antibody autoreactive with the $\alpha 1 / \alpha 2$ chains of type IV collagen. Am. J. Kidney Dis. 2005, 45, 397-406. [CrossRef]

29. McLeod, O.; Dunér, P.; Samnegård, A.; Tornvall, P.; Nilsson, J.; Hamsten, A.; Bengtsson, E. Autoantibodies against basement membrane collagen type IV are associated with myocardial infarction. Int. J. Cardiol. Heart Vasc. 2015, 6, 42-47. [CrossRef]

30. Bai, Y.; Wang, L.; Li, Y.; Liu, S.; Li, J.; Wang, H.; Huang, H. High ambient glucose levels modulates the production of MMP-9 and a5 (IV) collagen by cultured podocytes. Cell Physiol. Biochem. 2006, 17, 57-68. [CrossRef]

31. Monaco, S.; Sparano, V.; Gioia, M.; Sbardella, D.; di Pierro, D.; Marini, S.; Coletta, M. Enzymatic processing of collagen IV by MMP-2 (gelatinase A) affects neutrophil migration and it is modulated by extracatalytic domains. Protein Sci. 2006, 15, 2805-2815. [CrossRef]

32. Nikolov, A.; Tsinlikov, I.; Tsinlikova, I.; Nicoloff, G.; Blazhev, A.; Garev, A. Serum anti-collagen type IV IgM antibodies and development of diabetic nephropathy in diabetics with essential hypertension. Cent. Eur. J. Immunol. 2016, 41, 86. [CrossRef] [PubMed]

33. Nikolov, A.; Tzekova, M.; Blazhev, A. Relationship between lipid indices, type IV collagen turnover and the development of microvascular complications in diabetic patients with arterial hypertension. Folia Med. 2019, 61, 231-239. [CrossRef] [PubMed]

34. Nicoloff, G.; Blazhev, A.; Petrova, C.; Christova, P.; Jordanova-Laleva, P.; Dekov, D.; Dorovski, P. Detection of free antielastin antibodies among diabetic children. J. Investig. Med. 2005, 53, 128-134. [CrossRef] [PubMed]

35. Roy, S.; Ha, J.; Trudeau, K.; Beglova, E. Vascular basement membrane thickening in diabetic retinopathy. Curr. Eye Res. 2010, 35, 1045-1056. [CrossRef] [PubMed]

36. Tsilibary, E.C. Microvascular basement membranes in diabetes mellitus. J. Pathol. 2003, 200, 537-546. [CrossRef]

37. Kuiper, E.J.; van Zijderveld, R.; Roestenberg, P.; Lyons, K.M.; Goldschmeding, R.; Klaassen, I.; van Noorden, C.J.; Schlingemann, R.O. Connective tissue growth factor is necessary for retinal capillary basal lamina thickening in diabetic mice. J. Histochem. Cytochem. 2008, 56, 785-792. [CrossRef]

38. To, M.; Goz, A.; Camenzind, L.; Oertle, P.; Candiello, J.; Sullivan, M.; Henrich, P.B.; Loparic, M.; Safi, F.; Eller, A.; et al. Diabetesinduced morphological, biomechanical, and compositional changes in ocular basement membranes. Exp. Eye Res. 2013, 116, 298-307. [CrossRef]

39. Ziyadeh, F.N. Renal tubular basement membrane and collagen type IV in diabetes mellitus. Kidney Int. 1993, 43, 114-120. [CrossRef]

40. Nishikawa, T.; Giardino, I.; Edelstein, D.; Brownlee, M. Changes in diabetic retinal matrix protein mRNA levels in a common transgenic mouse strain. Curr. Eye Res. 2000, 21, 581-587. [CrossRef]

41. Liu, D.; Razzaque, M.S.; Cheng, M.; Taguchi, T. The renal expression of heat shock protein 47 and collagens in acute and chronic experimental diabetes in rats. Histochem. J. 2001, 33, 621-628. [CrossRef]

42. Iglesias-de la Cruz, M.C.; Ziyadeh, F.N.; Isono, M.; Kouahou, M.; Han, D.C.; Kalluri, R.; Mundel, P.; Chen, S. Effects of high glucose and TGF- $\beta 1$ on the expression of collagen IV and vascular endothelial growth factor in mouse podocytes. Kidney Int. 2002, 62, 901-913. [CrossRef]

43. Derosa, G.; Avanzini, M.A.; Geroldi, D.; Fogari, R.; Lorini, R.; de Silvestri, A.; Tinelli, C.; d'Annunzio, G. Matrix metalloproteinase 2 may be a marker of microangiopathy in children and adolescents with type 1 diabetes. Diabetes Care 2004, 27, 273-275. [CrossRef]

44. Uemura, S.; Matsushita, H.; Li, W.; Glassford, A.J.; Asagami, T.; Lee, K.H.; Harrison, D.G.; Tsao, P.S. Diabetes mellitus enhances vascular matrix metalloproteinase activity: Role of oxidative stress. Circ. Res. 2001, 88, 1291-1298. [CrossRef] [PubMed]

45. Peeters, S.A.; Engelen, L.; Buijs, J.; Chaturvedi, N.; Fuller, J.H.; Schalkwijk, C.G.; Stehouwer, C.D. Plasma levels of matrix metalloproteinase-2,-3,-10, and tissue inhibitor of metalloproteinase-1 are associated with vascular complications in patients with type 1 diabetes: The EURODIAB prospective complications study. Cardiovasc. Diabetol. 2015, 14, 1-10. 
46. Jacqueminet, S.; Abdesselam, O.B.; Chapman, M.J.; Nicolay, N.; Foglietti, M.J.; Grimaldi, A.; Beaudeux, J.L. Elevated circulating levels of matrix metalloproteinase-9 in type 1 diabetic patients with and without retinopathy. Clin. Chim. Acta 2006, 367, 103-107. [CrossRef]

47. Jayashree, K.; Yasir, M.; Senthilkumar, G.P.; Babu, K.R.; Mehalingam, V.; Mohanraj, P.S. Circulating matrix modulators (MMP-9 and TIMP-1) and their association with severity of diabetic retinopathy. Diabetes Metab. Syndr. 2018, 12, 869-873. [CrossRef] [PubMed]

48. Thrailkill, K.M.; Bunn, R.C.; Moreau, C.S.; Cockrell, G.E.; Simpson, P.M.; Coleman, H.N.; Frindik, J.P.; Kemp, S.F.; Fowlkes, J.L. Matrix metalloproteinase-2 dysregulation in type 1 diabetes. Diabetes Care 2007, 30, 2321-2326. [CrossRef]

49. Rogowicz, A.; Zozulinska, D.; Wierusz-Wysocka, B. The role of matrix metalloproteinases in the development of vascular complications of diabetes mellitus-clinical implications. Polskie Archiwum Medycyny Wewnetrznej 2007, 117, 43. [CrossRef] [PubMed]

50. Signorelli, S.S.; Malaponte, G.; Libra, M.; di Pino, L.; Celotta, G.; Bevelacqua, V.; Petrina, M.; Nicotra, G.S.; Indelicato, M.; Navolanic, P.M.; et al. Plasma levels and zymographic activities of matrix metalloproteinases 2 and 9 in type II diabetics with peripheral arterial disease. Vasc. Med. 2005, 10, 1-6. [CrossRef] [PubMed]

51. Kostov, K.; Blazhev, A.; Atanasova, M.; Dimitrova, A. Serum concentrations of endothelin-1 and matrix metalloproteinases-2,-9 in pre-hypertensive and hypertensive patients with type 2 diabetes. Int. J. Mol. Sci. 2016, 17, 1182. [CrossRef] [PubMed] 